\title{
Examining the Role of Job Resources on Work Engagement in the Academic Setting
}

\author{
Adel A. Y. Alzyoud ${ }^{1}$, Siti Z. Othman ${ }^{1} \&$ Mohd F. Mohd Isa ${ }^{1}$ \\ ${ }^{1}$ College of Business, Universiti Utara Malaysia, Malaysia \\ Correspondence: Adel A. Y. Alzyoud, College of Business, Universiti Utara Malaysia, Malaysia. E-mail: \\ adel_zyoud@yahoo.com
}

Received: September 25, 2014

Accepted: October 20, 2014 Online Published: December 30, 2014

doi:10.5539/ass.v11n3p103

URL: http://dx.doi.org/10.5539/ass.v11n3p103

\begin{abstract}
The aim of this study is to examine the relationship between job resources, namely autonomy, social support and performance feedback and work engagement. Data were gathered through questionnaire from a sample of academicians $(\mathrm{n}=532)$ who worked in four public universities (Mu'tah University, The University of Jordan, The Hashemite University and Yarmouk University) located in the southern, middle and northern region of Jordan. Results indicate that autonomy, social support and performance feedback were a significant factor in influencing academicians work engagement. These findings generally supported past findings, which suggested that employees are more likely to engage with their work if they are given the autonomy, social support and performance feedback. The findings were discussed and implications were also put forward.
\end{abstract}

Keywords: work engagement, job resources, autonomy, social support, performance feedback

\section{Introduction}

Organizations are becoming more convinced that staff engagement is the secret to maintaining business success and profitability. One of the reasons why organizations start to place greater emphasis on employees' work engagement is because it has positive and beneficial consequences at the individual and organizational levels, and these include organizational commitment, physical health and business-unit performance. In fact, past studies have shown how engaged employees tend to be more satisfied with their jobs, feel more committed to the organization, and do not intend to leave the organization (Demerouti, Bakker, De Jonge, Janssen, \& Schaufeli, 2001; Schaufeli \& Bakker, 2004; Schaufeli \& Salanova, 2007). In other words, high levels of work engagement can lead to greater commitment and satisfaction, lower absenteeism and quit rates, improved health and well-being, and better in-role and extra-role performance.

However, to achieve a high level of engaged employees and to ensure engaged employees stay engaged is not an easy task. In most situations, management influences the job demands and resources of their employees as they are the one who have the legitimate power to influence work conditions. In the academic context for example, teaching has been considered to be one of the most stressful occupations, and this is due to a high workload, inadequate salary, large class sizes, emotional demands, student misbehavior and the perceived low status of the profession (Burke \& Greenglass, 1994; Carlson \& Thompson, 1995; Hakanen, Bakker, \& Schaufeli, 2006; Konermann-van Hunsel, 2012; Kyriacou \& Sutcliffe, 1978). Studies have shown how high teaching commitments, and pressure in attracting external funding have become the sources of job-related stress for academics, while high role conflict such as demands of teaching, research, and administration has been related to high levels of job dissatisfaction and anxiety (Gillespie, Walsh, Winefield, Dua \&Stough, 2001; Kinman, 2001; Winefield, Boyd, Saebel, \& Pignata, 2008; Sonnentag \& Frese, 2003; Winefield, Gillespie, Stough, Dua, Hapuarachchi, \& Boyd, 2003).

In Australia, Rea (2011) found that research and teaching staffs in universities work very long hours to cover their workloads and they are the most dissatisfied. As a result, nearly half of the academic workforce in Australian universities intends to move to overseas universities or leave the higher education in the next 10 years (Burke, 2011). In other part of the globe, Alrai (2010) found that 776 university professors with $\mathrm{PhD}$ from Jordanian universities left their work between September 2007 and September 2008, and this number comprise of 17 percent of the total number of professors working in universities. Among the reasons these academics left the universities was lack of satisfaction. Batikhi (2012), head of Jordanian Association for Scientific Research 
(JASR) has pointed out the poor organizational support in public universities in Arab countries where the academic staff have little financial support to conduct their researches as compared to universities in other countries. Thus, organization needs to work on how to design a job that can inrease employee engagement.

Therefore, the purpose of this paper is to report findings of a research study that explored the possible influence of job resources such as autonomy, social support and performance feedback on work engagement among the academicians. We were particularly interested in discovering about whether academics work engagement was influenced by the job resources provided by the university.

\section{Literature Review}

\subsection{Work Engagement}

The concept of work engagement was first coined by Kahn in 1990, who defined it as "the harnessing of organizational members' selves to their work roles" (p. 694). It is the extent to which an individual is attentive and absorbed in the performance of his or her work. Kahn (1990) argued that when people are engaged, they are not only are physically involved in their work, but they also are cognitively alert and emotionally connected to others at the moment of engagement. However, the level of work engagement varies across individuals as the amount of energy and dedication they contribute to their job is different.

This concept has evolved through the years and has been regarded as a worthwhile concept by many researchers in studying burnout, health, job satisfaction, job performance and turnover intention of employees. Maslach and Leiter (1997) for example, have referred work engagement as the opposite of job burnout by defining burnout as an erosion of engagement. They argued that while burnout is defined by exhaustion, cynicism, and inefficacy, engagement is the direct opposite where energy replaces emotional exhaustion, involvement replaces cynicism, and a sense of efficacy replaces lack of professional accomplishment.

May, Gilson, and Harter's (2004) definition of work engagement was quite similar as what has been previously defined by Kahn (1990). They believed that work engagement consists of three components: physical - the energy used to perform a job, emotional - putting one's heart in one's job, and cognitive - being engrossed in a job. On the other hand, Schaufeli, Martinez, Pinto, Salanova and Bakker (2002, p. 24) defined work engagement as a "positive, fulfilling, work-related state of mind that is characterized by vigor, dedication and absorption." They refer vigor as high levels of energy and mental resilience that related to work experience, and one's eagerness to invest effort in work and to persist even when faced with problems. Individual will feel motivated, eager and excited about his or her work even when they faced with setbacks, limitations or challenges. Dedication is more of being deeply involved in one's work and experiencing feelings of importance, passion, motivation and challenge. In other words, dedicated individuals would be happily involved in their work and felt that their work is important, meaningful and challenging. Finally, absorption is described as being content and having a total concentration on one's work.

In the past, various predictors of work engagement have been studied and these include organizational commitment distributive, procedural justice, rewards and recognition; person-job fit and person-organization fit; leadership style (Babcock-Roberson \& Strickland, 2010; Hamid \& Yahya, 2011; Kimura, 2011; Leithwood \& Jantzi, 1999; Saks, 2006; Tims, Bakker, \& Xanthopoulu, 2011). However, work engagement has been mostly analyzed by the job demands-resources model. The model offers two assumptions regarding the predictors and outcomes of engagement at work. First, job resources such as peers and supervisors support, autonomy as well feedback, is assumed to commence a activational manner that guide to engagement at workplace, thus, lead to advanced performing. The following notion is that in a high demands situation (e.g. workload, emotional demands, and mental demands) job resources will become more prominent and gain their motivational potential (Bakker \& Demerouti, 2007; Demerouti, Bakker, Nachreiner, \& Schaufeli, 2001).

This model has also been used to predict the influence of job characteristic, in terms of job demands and job resources on individual's well-being (Bakker, Demerouti, Taris, Schaufeli, \& Schreurs, 2003). First is the process of exhaustion where job demands gradually reduce the mental and physical energy reserves that will finally lead to tiredness, burnout and other related health problems like a healthy grievance and functional disorder (authorized leave). Second is the activational manner where resources rise the preparedness to expend strength or to work hard. This at the end of the day will lead to engagement, to be commited and more activational consequences, as organizational citizenship behavior (OCB). Equally, collapse and enthusiasm manner have earned experimental support from numerous researches (e.g., Bakker, Demerouti, Taris, Schaufeli, \& Schreurs, 2003; Bakker, Demerouti, \&Verbeke, 2004). 


\subsection{Job Resources}

Job resources are known to influence employee well-being intrinsically or extrinsically. As intrinsic motivators, job resources will satisfy the needs for autonomy, competence and individuals' growth and development (Bakker \& Demerouti, 2007; Ryan \& Deci, 2000). For example, supervisory coaching can improve job competence, while involvement in decision-making and colleague or supervisory support might fulfill the necessity for autonomy. Job resources might as well act as outer motivators. According to Schaufeli and Bakker (2004), and Bakker and Demerouti (2007) in a resourceful environments which includes supportive peers and performance feedback, the likelihood of being successful in completing one's task and achieving one's work goal may increase. It is expected that an appropriate supply of job resources might supplement employees' work engagement while their deficiency can hinder goal accomplishment, and this may lead employees to develop a negative and cynical attitude towards their work.

In line with the views about job resources being a enthusiasm role, many past researches have exposed a positive association amongst job resources components such as social support, performance feedback and autonomy and work engagement in various settings and countries (Bakker \& Demeroutti, 2007, 2008; Buys \& Rothmann, 2010; Lee Ashforth, 1996; Lin, Oi-ling, Kan, \& Xin-wen, 2009; Korunka, Kubicek, Schaufeli, \& Hoonakker, 2009; Nahrgang, Morgeson, \& Hofmann, 2011; Rothmann \& Joubert, 2007; Saks, 2006; Schaufeli \& Bakker, 2004; Taipale, Selander, Antilla, \& Natti, 2011). For example, a 3-year panel study on 2,555 Finnish dentists have shown how job resources such as opportunity to be creative (craftsmanship) and receiving positive feedback were positively related to work engagement (Hakanen, Perhoniemi, \& Toppinen-Tanner, 2008). Similar findings were also found in a study conducted by Schaufeli, Bakker and Van Rhenen (2009) where rises in autonomy, support and feedback have positively predicted future work engagement and reduced sickness absenteeism.

In another longitudinal study of 163 employees in electrical engineering and electronic company in Netherland, Xanthopoulu, Bakker, Demerouti and Schaufeli (2009) found that work engagement are best explained when all the dimensions of job resources such as autonomy, social support, and performance feedback are simultaneously taken into account.The findings support previous study conducted by Lloren, Bakker, Schaufeli and Salanova (2006) on employees in Spain and Holland, where employee's motivation, determination and interest to work were depend on whether the organizations provide the needed resources or not.

In a survey of over two thousand school teachers in Finland, Hakanen, Bakker and Schaufeli (2006) found positive relationship between job resource in the form of job control, information and supervisory support and work engagement. A year later, Bakker, Hakanen, Demerouti, and Xanthopoulou (2007) found similar findings whent tested on instructors hiring in multi level schools. In 2010, Bakker and Bal conducted a study on six different teacher training colleges and found that job resources have motivational potential that enhance teachers' week-levels of work engagement.

Study also has shown how job resources becoming further prominent as well as gaining their enthusiasm effort while workers are defied with great demands. In a study involving Finnish dentists with high job demand such as workload, Hakanen, Bakker, and Demerouti (2005) established that job resources alike changeability in the necessary qualified abilities and interactions were utmost suitable in sustaining engagement at work.

Based on the discussions presented above, the following hypotheses are proposed:

H1: Autonomy is positively related to work engagement

$\mathrm{H} 2$ : Social support is positively related to work engagement

H3: Performance feedback is positively related to work engagement

\section{Research Framework}

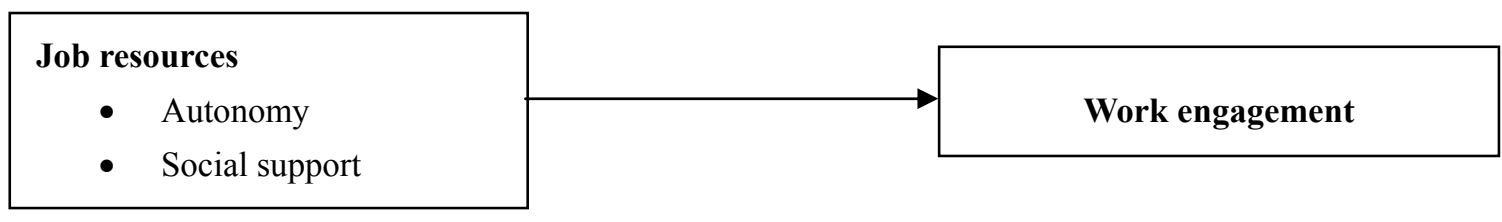

Figure 1. Research framework

Figure 1 shows the research framework tested in this study. The research framework is developed based on social exchange theory (Blau, 1964), Job Demands-Resources (JD-R) Model (Demerouti \& Bakker, 2011), as 
well as the discussion of literature on work engagement (Bakker \& Demerouti, 2007; Bakker, Demerouti, Taris, Schaufeli, \& Schreurs, 2003; Demerouti, Bakker, Nachreiner, \& Schaufeli, 2001).The research framework shows the relationship between job resources (autonomy, social support, feedback performance) and work engagement. Job resources was the independent variable while work engagement was the dependent variable.

\section{Methodology}

\subsection{Research Design}

Quantitative research design is used in this study as it allows the testing of relationship between variables using statistical methods. This corresponds with the primary objective of this study, which is to examine the relationship between job resources and work engagement. Apart from that, this study is conducted in the natural environment of the organization where the researcher interference is minimal. The unit of analysis is at the individual level (academic staffs) asrespondents' perceptions about the job resources become the basis for understanding their influence on work engagement. The primary data for this study was collectedat one point of time (cross-sectional study) through distribution of questionnaire.

\subsection{Participants}

430 male and 102 female respondents have took part in this study. The average age for the respondents 51 years old. Out of 532 respondents, $86.2 \%$ of them were married. All of the respondents had higher academic qualifications of doctoral degree. 53.9\% of the respondents had earning between USD2001 and USD3000 per month. Most of the respondents had been in their position for 1-3 years $(42.9 \%)$ and had served their organizations for $1-3$ years $(55.3 \%)$. Associate professors made up $35.1 \% \%$ of the total respondents. The rest consisted of professors, assistant professors, instructors and lecturers.

\subsection{Measurements}

Measures for work engagement were adapted from Schaufeli and Baker (2003). The 17-items work engagement scale measured academician's perception on his/her work-related state of mind. The measurement for job resources consist of three dimensions namely, autonomy, social support and feedback performance. Items for autonomy and social support were adapted from Karasek (1985) while items for feedback performance were adapted from Sims, Szilagyi, and Keller (1976). The 3-items autonomy scale assessed the extent of freedom, independence, and discretion of an academican to plan his/her work pace and method; the 8-items social support scale assessed academicians' interpersonal coping resource where one person helps another and enhances that person's well-being; and the 4-items performance feedback scale assessed the extent to which an academician knows his/her own job performance from the job itself, colleagues, or supervisors.In this study, each of the adapted questions asked how strongly the respondents agreed or disagreed with the work engagement and job resources statements on a five-point scale whereby, $1=$ strongly disagree, and $5=$ strongly agree.

\section{Results}

Table 1 presents the internal consistency reliabilities (Cronbach's Alpha), means, standard deviations, and Pearson correlations of variables for the 532 participants. As shown in Table 1, the Cronbach's Alpha for the work engagement measure was .74. The three sub-scales of the 15 item job resources (autonomy, social support and performance feedback) also have satisfactory reliability values ranging from .77 to .82 . Job resources were significantly positively related with work engagement $(r=0.49, \mathrm{p}<0.01)$. This result implies that participants who received higher job resources had higher work engagement. Table 1 also revealed significant clear positive correlation amongst all the resources components and engagement, with correlation coefficients between .24 and .51.These results indicates that the more the participants received job autonomy, social support and performance feedback, the more engaged they are with their work.

Table 1. Reliability statistics, descriptive statistics and correlations

\begin{tabular}{lllllllll}
\hline Variables & $\alpha$ & $\mathrm{M}$ & $\mathrm{SD}$ & 1 & 2 & 3 & 4 & 5 \\
\hline Job resources (15 items scale) & .75 & 3.61 & .48 & - & & & & \\
Autonomy & .82 & 3.77 & .82 & $.34^{* *}$ & - & & & \\
Social support & .82 & 3.59 & .70 & $.82^{* *}$ & -.05 & - & & \\
Performance feedback & .77 & 3.54 & .76 & $.57^{* *}$ & $.10^{*}$ & $.14^{* *}$ & - & \\
Work engagement & .74 & 3.71 & .43 & $.49^{* *}$ & $.51^{* *}$ & $.27^{* *}$ & $.24^{* *}$ & - \\
\hline
\end{tabular}

Note: $\mathrm{n}=532 ;{ }^{* *} \mathrm{p}<0.01 ; \alpha=$ reliability; $\mathrm{M}=$ mean; $\mathrm{SD}=$ standard deviation 
To test hypothesis 1, 2 and 3, regression analysis was conducted. Results in Table 2 showed that $37 \%\left(R^{2}=0.37\right.$, $\mathrm{F}=103.18, \mathrm{p}<0.01)$ of the variance in work engagement was significantly explained by autonomy, social support and performance feedback. In the model, autonomy $(\beta=0.51, p<0.01)$, social support $(\beta=0.28, p<0.01)$ and performance feedback $(\beta=0.16, \mathrm{p}<0.01)$ were found positively associated with work engagement. Therefore, hypothesis 1,2 and 3 were supported.

Table 2. Regression results of proactive personality on work engagement

\begin{tabular}{cccccc}
\hline & \multicolumn{2}{c}{ Unstandardized Coefficients } & Standardized Coefficients & $\mathrm{t}$ & Sig. \\
\cline { 2 - 6 } & $\beta$ & Std. Error & $\beta$ & & \\
\hline (Constant) & 1.79 & .12 &. & 15.12 & $.000^{* *}$ \\
Autonomy & .27 & .02 & .51 & 14.53 & $.000^{* *}$ \\
Social Support & .17 & .02 & .28 & 7.95 & $.000^{* *}$ \\
Performance feedback & .09 & .02 & .16 & 4.47 & $.000^{* *}$ \\
\hline
\end{tabular}

$* * \mathrm{p}<0.01 ; \mathrm{R}^{2}=0.37 ; \mathrm{F}=103.18$

\section{Discussions, Limitation and Direction for Future Research}

In this study, work engagement was assessed by job resources like autonomy, social support and performance feedback. The results show that there was an association between all the job resources components and work engagement. This finding is consistent with the theoretical prediction of the JD-R model, which claims that job resources lead to high work engagement (Bakker \& Demeroutti, 2007; Schaufeli \& Bakker 2004). It is also consistent with previous studies on job resources and work engagement (Bakker \& Demerouti, 2007, 2008; Bakker, Demerouti \& Verbeke, 2004; Demerouti, Bakker, De Jonge, Janssen, \& Schaufeli, 2001; Mauno, Kinnunen, \& Ruokolainen, 2007; Schaufeli \& Bakker, 2004; Schaufeli, Bakker, \& Salanova, 2006).

The present study expanded this prospective evidence to Jordanian academics' staff and suggests that resources of job (autonomy, thesocial support besides feedback) are predictors of work engagement. When academics experience greater autonomy, social support and performance feedback at work, they may be more likely to find a way to make their work more pleasant, participate in their workplace decision in order to increase their involvement in their work and workplace, and thus increase their commitment to their work. Therefore, through strong autonomy, social support and performance feedback relationships, employees appear better equipped to cope with challenges at work place and show to understand their work more meaningful. Further to the point made above, the significant relationship job resources on work engagement among academicians can influences their level of contributions to enhance the performance of their universities.

There are limitations in the design of this study that might influence the interpretations and generalizations of these findings. This study only concentrated on academics in four public universities in Jordan. Different results might be obtained if the study is conducted in private universities and universities at different geographical areas. Based on the regression model, job resources only explains $37 \%$ of the variance in work engagement. This indicates that there are other potential factors that might influence academics' work engagement such as leadership style, individual characteristics and job characteristics. Hence, it is suggested that future research should replicate the framework of this study by incorporating the mentioned factors to elicit a comprehensive understanding on how personal, organizational, and environmental factors affect academics' work engagement.

\section{Conclusion}

The current research findings revealed that all three components of resources (autonomy, social support and performance feedback) tested in this study were found to be a strong predictor of work engagement among the academics in higher education institutions. It gives the impression that academicians are willing to put extra effort in their works when these resources are perceived to be present. In this paper, the researcher expected to show engagement is predicted by job resources and leads to a higher engaged workforce. It is hoped that through the examination of how job resources relate to work engagement, a more complete understanding of the kind of effort needed to increase academics engagement towards their work will be achieved.

\section{References}

Babcock-Roberson, M. E., \& Strickland, O. J. (2010). The relationship between charismatic leadership, work engagement, and organizational citizenship behaviors. The Journal of psychology, 144(3), 313-326. http://dx.doi.org/10.1080/00223981003648336 
Bakker, A. B., \& Bal, M. P. (2010). Weekly work engagement and performance: A study among starting teachers. Journal of Occupational and Organizational Psychology, 83(1), 189-206. http://dx.doi.org/10.1348/ 096317909X402596

Bakker, A. B., \& Demerouti, E. (2007). The job demands-resources model: State of the art. Journal of Managerial Psychology, 22(3), 309-328. http://dx.doi.org/10.1108/02683940710733115

Bakker, A. B., \& Demerouti, E. (2008). Towards a model of work engagement. Career Development International, 13(3), 209-223.

Bakker, A. B., Demerouti, E., Taris, T. W., Schaufeli, W. B., \& Schreurs, P. J. G. (2003). A multigroup analysis of the job demands-resources model in four home care organizations. International Journal of Stress Management, 10(1), 16-38. http://dx.doi.org/10.1037/1072-5245.10.1.16

Bakker, A. B., Demerouti, E., \&Verbeke, W. (2004). Using the job demands-resources model to predict burnout and performance. Human Resource Management, 43(1), 83-104. http://dx.doi.org/10.1002/hrm.20004

Bakker, A. B., Hakanen, J. J., Demerouti, E., \& Xanthopoulou, D. (2007). Job resources boost work engagement, particularly when job demands are high. Journal of Educational Psychology, 99(2), 274-284. http://dx.doi.org/10.1037/0022-0663.99.2.274

Blau, P. M. (1964). Exchange and power in social life. New York: Wiley

Burke, R. J., \& Greenglass, E. R. (1994).Towards an understanding of work satisfactions and emotional well-being of school-based educators. Stress medicine, 10(3), 177-184. http://dx.doi.org/10.1002/smi. 2460100307

Buys, C., \& Rothmann, S. (2010). Burnout and engagement of reformed church ministers. South African Journal of Industrial Psychology, 26(1), 309-328. http://dx.doi.org/10.4102/sajip.v36i1.825

Carlson, B. C., \& Thompson, J. A. (1995). Job burnout and job leaving in public school teachers: Implications for stress management. International journal of stress management, 2(1), 15-29.

Demerouti, E., Bakker, A. B., De Jonge, J., \& Janssen, P. P. M. (2001). Burnout and engagement at work as a function of demands and control. Scandinavian Journal of Work Environment Health, 27(4), 279-286.

Demerouti, E., Bakker, A. B., Nachreiner, F., \& Schaufeli, W. B. (2001). The job demands-resources model of burnout. Journal of Applied Psychology, 86(3), 499-512. http://dx.doi.org/10.1037/0021-9010.86.3.499

Gillespie, N. A., Walsh, M., Winefield, A. H., Dua, J., \& Stough, C. (2001). Occupational stress in universities: Staff perceptions of the causes, consequences and moderators of stress. Work \& Stress, 15, 53-72. http://dx.doi.org/10.1080/02678370110062449

Hakanen, J. J., Bakker, A. B., \& Demerouti, E. (2005). How dentists cope with their job demands and stay engaged: The moderating role of job resources. European Journal of Oral Sciences, 113(6), 479-487. http://dx.doi.org/10.1111/j.1600-0722.2005.00250.x

Hakanen, J. J., Bakker, A. B., \& Schaufeli, W. B. (2006). Burnout and work engagement among teachers. Journal of School Psychology, 43(6), 495-513. http://dx.doi.org/10.1016/j.jsp.2005.11.001

Hakanen, J. J., Perhoniemi, R., \& Toppinen-Tanner, S. (2008). Positive gain spirals at work: From job resources to work engagement, personal initiative and work-unit innovativeness. Journal of Vocational Behavior, 73(1), 78-91. http://dx.doi.org/10.1016/j.jvb.2008.01.003

Hamid, S. N. A., \& Yahya, K. K. (2011). Relationship between person-job fit and person-organization fit on employees' work engagement: A study among engineers in semiconductor companies in Malaysia. Paper presented at the Annual Conference on Innovations in Business \& Management, London, UK.

Kahn, W. A. (1990). Psychological conditions of personal engagement and disengagement at work. Academy of Management Journal, 692-724. http://dx.doi.org/10.2307/256287

Kimura, T. (2011). Empowerment, P-O Fit, and work engagement -A Mediated Moderation Model-. European Journal of Economics, Finance and Administrative Sciences, (38), 44-58.

Kinman, G. (2001). Pressure points: A review of research on stressors and strains in UK academics. Educational Psychology, 21, 473-492. http://dx.doi.org/10.1080/01443410120090849

Lee, R. T., \& Ashforth, B. E. (1996). A meta-analytic examination of the correlates of the three dimensions of job burnout. Journal of Applied Psychology, 81(2), 123. http://dx.doi.org/10.1037/0021-9010.81.2.123 
Leithwood, K., \& Jantzi, D. (1999). The relative effects of principal and teacher sources of leadership on student engagement with school. Educational Administration Quarterly, 35(5), 679-706. http://dx.doi.org/10.1177/ 0013161 X99355002

Lin, L., Oi-ling, S., Kan, S., \& Xin-wen, B. (2009). Challenge and hindrance job demands, job resource, and their relationships with vigor and emotional exhaustion. Paper presented at the International Conference on Management Science \& Engineering, Beijing, China.

Llorens, S., Bakker, A. B., Schaufeli, W., \& Salanova, M. (2006).Testing the robustness of the job demands-resources model. International Journal of Stress Management, 13(3), 378-391. http://dx.doi.org/ $10.1037 / 1072-5245.13 .3 .378$

Karasek, R. A. (1985). Job content questionnaire and user's guide. Los Angeles: University of Massachusetts Press.

Konermann-van Hunsel, J. F. E. (2012). Teachers' work engagement: A deeper understanding of the role of job and personal resources in relationship to work engagement, its antecedents and its outcomes. Retrieved January 25, 2013, from http://doc.utwente.nl/7900/1/thesis_J_Konermann.pdf

Korunka, C., Kubicek, B., Schaufeli, W. B., \& Hoonakker, P. (2009). Work engagement and burnout: Testing the robustness of the job demands-resources model. The Journal of Positive Psychology, 4(3), 243-255. http://dx.doi.org/ 10.1080/17439760902879976

Kyriacou, C., \& Sutcliffe, J. (1978). Teacher stress: Prevalence, sources, and symptoms. British Journal of Educational Psychology, 48(2), 159-167. http://dx.doi.org/10.1111/j.2044-8279.1978.tb02381.x

Maslach, C., Schaufeli, W. B., \& Leiter, M. P. (2001). Job burnout. Annual Review of Psychology, 52(1), 397-422. http://dx.doi.org/10.1146/annurev.psych.52.1.397

Mauno, S., Kinnunen, U., \& Ruokolainen, M. (2007). Job demands and resources as antecedents of work engagement: A longitudinal study. Journal of Vocational Behavior, 70(1), 149-171. http://dx.doi.org/10.1016/j.jvb.2006.09.002

May, D. R., Gilson, R. L., \& Harter, L. M. (2004). The psychological conditions of meaningfulness, safety and availability and the engagement of the human spirit at work. Journal of Occupational and Organizational Psychology, 77(1), 11-37. http://dx.doi.org/10.1348/096317904322915892

Nahrgang, J. D., Morgeson, F. P., \& Hofmann, D. A. (2011). Safety at work: A meta-analytic investigation of the link between job demands, job resources, burnout, engagement, and safety outcomes. Journal of Applied Psychology, 96(1), 71-94. http://dx.doi.org/10.1037/a0021484

Rothmann, S., \& Joubert, J. (2007). Job demands, job resources, burnout and work engagement of managers at a platinum mine in the North West Province. South African Journal of Business Management, 38(3), 49-61.

Saks, A. M. (2006). Antecedents and consequences of employee engagement. Journal of Managerial Psychology, 21(7), 600-619. http://dx.doi.org/10.1108/02683940610690169

Schaufeli, W. B., \& Bakker, A. B. (2003). UWES-utrecht work engagement scale: Test manual. Department of Psychology, Utrecht University.

Schaufeli, W. B., \& Bakker, A. B. (2004). Job demands, job resources, and their relationship with burnout and engagement: A multi-sample study. Journal of Organizational Behavior, 25(3), 293-315. http://dx.doi.org/ $10.1002 /$ job. 248

Schaufeli, Bakker, A. B., \& Salanova, M. (2006). The measurement of work engagement with a short questionnaire a cross-national study. Educational and psychological measurement, 66(4), 701-716. http://dx.doi.org/10.1177/0013164405282471

Schaufeli, W. B., Bakker, A. B., \& Van Rhenen, W. (2009). How changes in job demands and resources predict burnout, work engagement, and sickness absenteeism. Journal of Organizational Behavior, 30(7), 893-917. http://dx.doi.org/10.1002/job.595

Schaufeli, W. B., Martínez, I. M., Pinto, A. M., Salanova, M., \& Bakker, A. B. (2002). Burnout and engagement in university students. Journal of Cross-Cultural Psychology, 33(5), 464-481. http://dx.doi.org/10.1177/ 0022022102033005003

Schaufeli, W. B., \& Salanova, M. (2007). Work engagement. Managing Social and Ethical Issues in Organizations, 135-177. 
Sims, H. P., Jr., Szilagyi, A. D., \& Keller, R. T. (1976). The measurement of job characteristics. Academy of Management Journal, 195-212. http://dx.doi.org/10.2307/255772

Taipale, S., Selander, K., Anttila, T., \& Nätti, J. (2011). Work engagement in eight European countries: The role of job demands, autonomy, and social support. International Journal of Sociology and Social Policy, 31(7/8), 486-504. http://dx.doi.org/10.1108/01443331111149905

Tims, M., Bakker, A. B., \& Xanthopoulou, D. (2011). Do transformational leaders enhance their followers' daily work engagement? The Leadership Quarterly Journal, 22(1), 121-131. http://dx.doi.org/10.1016/j.leaqua. 2010.12.011

Winefield, A. H., Boyd, C., Saebel, J., \& Pignata, S. (2008). Job stress in university staff: An Australian research study. Bowen Hills, Quensland: Australian Academic Press.

Winefield, A. H., Gillespie, N. A., Stough, C., Dua, J., Hapuarachchi, J., \& Boyd, C. (2003). Occupational stress in Australian university staff: Results from national survey. International Journal of Stress Management, 10, 51-63. http://dx.doi.org/10.1037/1072-5245.10.1.51

Ryan, R. M., \& Deci, E. L. (2000). Intrinsic and extrinsic motivations: Classic definitions and new directions. Contemporary Educational Psychology, 25(1), 54-67. http://dx.doi.org/10.1006/ceps.1999.1020

Xanthopoulou, D., Bakker, A. B., Demerouti, E., \& Schaufeli, W. B. (2009). Reciprocal relationships between job resources, personal resources, and work engagement. Journal of Vocational Behavior, 74(3), 235-244. http://dx.doi.org/10.1016/j.jvb.2008.11.003

\section{Copyrights}

Copyright for this article is retained by the author(s), with first publication rights granted to the journal.

This is an open-access article distributed under the terms and conditions of the Creative Commons Attribution license (http://creativecommons.org/licenses/by/3.0/). 